\title{
乳酸・グリコール酸共重合体ナノパーティクルの設計と 長期徐放性製剤への応用に関する研究
}

村上 秀樹

Hideki Murakami

\section{1. 研究を始めた動機}

本研究は, 平成 6 年 4 月から 1 年間, 岐阜薬科大学 川島嘉明教授の研究室へ留学する機会を得たことに端 を発する。本研究室では, 既に, 生体適合性および生 体内分解性を有する乳酸・グリコール酸共重合体 (PLGA) からなるナノサイズの薬物担体（ナノスフ ェア）について研究されていた。このナノスフェアは 相分離法を利用して製していたが，入社以来，固形製 剂の製剂化研究や工業化研究に従事してきた筆者にと って, PLGA, ナノスフェア, コアセルベーションと いった言葉は全く馴染みがなく、これから始まる研究 に対して不安を抱いたことを覚えている。研究開始 時, 川島教授から,「薬物を含有しないナノサイズの 粒子（ナノパーティクル）を製剤原料として開発して はどうか。」とアドバイスを頂き，未知の世界での挑 戦が始まった。

\section{2. 研究遂行上感じたこと}

まず，PLGAナノパーティクルを製剂原料として 使用するため, 製造効率の高い製法の確立に取り組ん だ。エマルション溶媒拡散法（SESD 法）は，本研究 室で既に確立されたPLGAナノパーティクルの調製 法である。この方法を初めてトレースした際, 無知で ある筆者にとっていろいろな疑問が浮かんだ。「分散 剂って何?」,「こんな薄い濃度の PLGA 溶液では, $1 \mathrm{~kg}$ のナノパーティクルを製するのにどれくらいの 溶媒量がいるの? 」,「なぜ, 製造性の悪い超遠心分離

2000 年 9 月 28 日受付

田辺製薬(株製品技術研究所

（示532-8505 大阪市淀川区加島 3丁目16-89）TEL 06-6300-2777

\section{<著者紹介>}

昭和59年 3 月京都薬科大学薬学部薬学科卒 業, 昭和 61 年 3 月同大学院薬学研究科博士前 期課程修了, 同年 4 月田辺製薬(怵入社, 平成 6 年 4 月から平成 7 年 4 月岐阜薬科大学製剤 学教室研究生, 現在田辺製薬(侏製品技術研究 所。平成 8 年第 2 回製剤と粒子設計シンポジ ウム奖励賞受賞。薬学博士。

専門: 製剤学。固形製剂の製剤化研究および 工業化研究に従事。
をナノパーティクルの捕集精製に用いているの?」な どである。そこで，これらの疑問点を一つひとつ紐解 いていった。分散剂であるポリビニルアルコール (PVA) については，その役割を解明し選択の最適化 を行うことができた。しかし，案の定，PLGA 溶液 の濃度を工業的に受け入れられる範囲まで上昇させる と，著しい凝集による収率の低下が起きた。これを更 に改良しょうと, “Try and error”の毎日。「エマル ションを形成させては䭾目だ。もっと拡散速度の速い 溶媒を用いなくては!」大きな方向転換であった。通 常のエマルション形成の概念を捨て検討した結果, 水 非混和性のジクロロメタンを水混和性のアルコールに 変更すれば良いことを見出した。また，限外滤過法を ナノパーティクルの捕集精製に適用することにより, 更に製造性を向上することができた。

次に, PLGAナノパーティクルの粉末を, 長期徐 放性製剂用の直接打錠用マトリックス基剂として開発 することに取り組んだ。圧縮成形や溶出制御は筆者に とって得意な分野である。しかし，困ったことに，長 期徐放性を示す成形体はいつ薬物溶出が終了するか分 からない。そのため, 毎日, 溶出をチェックする必 要があった。さらに，埋め込み型の PLGA ミ二錠で は，生体内において溶出が制御できないことが判明し た。またもや “Try and error”の連続。今回はさす がに諦めかけた。しかし，末端カルボキシル基をキャ ップしたPLGA のナノパーティクルを用いることに よって，これを回避できることを見出した。

これらの研究を通じて，何事に対しても，本質を見 極める目を持つことは勿論のこと，固定観念にとらわ れずに新しい事にチャレンジし，最後まで諦めないこ とが大切であると学んだような気がする。

\section{3. 主な研究成果}

本研究は, PLGA ナノパーティクルの設計と長期 徐放性製剂への適用に分けることができる。それぞれ の主要な成果を以下に示す。

\section{1 PLGA ナノパーティクルの設計}

SESD 法の製造効率性を向上させるために，十ノ パーティクルの生成に重要な役割を果すと考えられる 


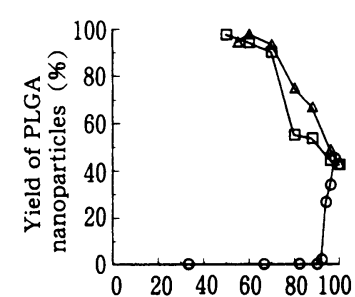

Acetone concentration (\%)

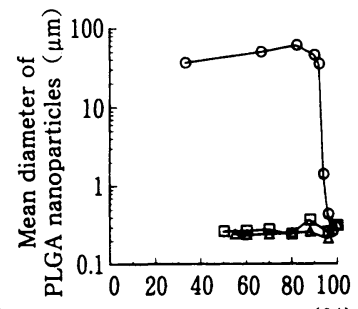

Acetone concentration (\%)
Fig. 1 Yield and mean diameter of PLGA (Mw : $4.68 \times 10^{4}$ ) nanoparticles as a function of acetone concentration in binary organic solvents

(O) Original SESD method (dichloromethane/ acetone)

$(\triangle)$ Modified-SESD method (ethanol/acetone)

( $\square$ ) Modified-SESD method (methanol/acetone)

分散剂 (PVA) の選択の最適化検討を行った。収率, および粒子径, 再分散性, フィルム形成性等の粒子特 性の観点から評価した結果, PVAの重合度よりけん 化度の方が重要であり, 低いけん化度の方が収率は良 好で，優れた粒子特性を示すことが明らかとなった。 次に, SESD 法のスケールアップ性を向上させるため に改良を加えた。SESD 法で PLGA の溶媒として用 いたジクロロメタン/アセトン（PLGA に対して良溶 媒／良溶媒）の混合溶媒を, 水混和性のアルコール／ アセトン（PLGAに対して貧溶媒／良溶媒）にするこ とにより，広範囲の混合比において PLGA ナノパー ティクル高収率で得られることを見出した（Fig. 1)。 また, 改良型 SESD 法を, 分子量, 組成比, 製造元 の異なる PLGA へ適用した結果, 乳酸・グリコール 酸の組成比が $75 / 15$ 以上の PLGA ではアセトン/ア ルコールが, $50 / 50$ ではアセトニトリル /アルコー ルが収率の上で優れていることがわかった。更に,

PLGA と PVA の溶媒からの相分離結果から, 二種類 の溶媒組成の最適選択法を見出し，本法の適用性を拡 大することができた。

3. 2 PLGA ナノパーティクルの長期徐放性製剂へ の応用

改良型 SESD 法により得られたPLGA ナノパーテ イクル䣄濁液を粉末化し, 直接打錠用賦形剂として評 価した。PLGA 粒子は，ナノサイズにすることによ りその压縮成形性は著しく向上し, 薬物溶出は, 低い PLGA ナノパーティクル含量の場合では数時間, 高 含量の場合では 1 ヶ月にわたって制御できることがわ かった。更に，本マトリックス錠からの薬物溶出特性 について評価を行った結果, PLGA ナノパーティク ルの種類, 種類の異なる PLGA ナノパーティクルの

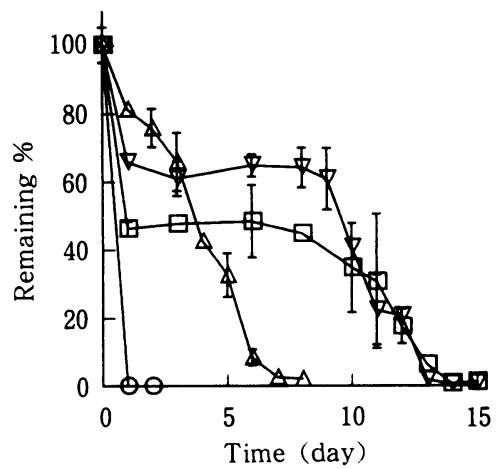

Fig. 2 Remaining percentage of theophylline in mini-tablets after s.c. administration to rats

Mini-tablets were prepared with $80 \%$ nanoparticles.

(○) PLGA ( $\mathrm{Mw}: 4.17 \times 10^{3}$ ),

$(\triangle)$ EC-PLGA $1\left(\mathrm{Mw}: 1.17 \times 10^{4}\right)$,

(口) EC-PLGA $2\left(\mathrm{Mw}: 2.01 \times 10^{4}\right)$,

( $\nabla)$ EC-PLGA $2 / 3$

$\left(\mathrm{Mw}: 2.01 \times 10^{4} / 6.00 \times 10^{3}(8 / 2)\right)$

混合比, 錠剤重量, サイズを変えることによって, 薬 物溶出を任意に制御できることがわかった。本製剂 は, 設計, 薬物溶出の予測が容易で, 小型化 (ミニ 錠）することにより生体内埋め込み型製剂への適用性 が示唆された。ミ二錠の薬物溶出に及ぼす因子を in vitroで評価した結果, 薬物溶出は試験液の $\mathrm{pH}$ の 影響を著しく受けることがわかった。しかし，末端 カルボキシル基をキャップした PLGA（EC-PLGA） を用いることによってそれを回避できることを見出し た（Fig. 2)。更に，in vivo評価により， EC-PLGA のミ二錠は生体内でも薬物溶出を制御し, $\mathrm{pH}$ \% Mcllvaine 緩衝液を用いた in vitro結果と相関性が 高いことを明らかにした。

\section{4. おわりに}

本研究では, PLGA ナノパーティクルの製造性, 粒子特性の向上の観点から粒子設計を行い, 長期徐放 性製剂用の直接打錠用マトリックス基剤に係わる諸課 題を解決し, 埋め込み型ドラッグデリバリーシステム の新しい設計法を提示することができた。今後, 本シ ステムは, 粘膜透過性がそしく生体内半減期が短いペ プチド性薬物等への適用が期待される。

最後に, 本研究の遂行に対して, 終始御懇篤なる御 指導御鞭撻を賜りました岐阜薬科大学製剂学教室川島 嘉明教授, 竹内洋文助教授に深く感謝の意を表しま す。

(学位取得は 2000 年 6 月, 岐阜薬科大学) 